Journal of Sustainable Development of Transport and Logistics

journal home page: http://jsdtl.sciview.net

\title{
Conceptual and methodological approaches to evaluation of investment attractiveness of enterprises engaged in transportations
}

\section{Olha Myshkovych}

Ternopil Ivan Pul'uj National Technical University,

56, Ruska str., 46001 Ternopil, Ukraine

e-mail: rudaolya@mail.ru

PhD, Assistant Professor, Department of Transport Technology

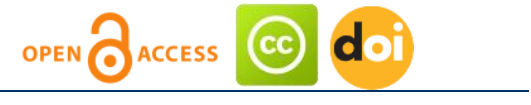

\section{Article history:}

Received: October, 2016

1st Revision: October, 2016

Accepted: November, 2016

\section{DOI:}

10.14254/jsdtl.2016.1-1.6

\begin{abstract}
The aim of the article is to analyze the conceptual and methodological approaches to determining the investment attractiveness of enterprises engaged in transportations. It is indicated that the investment attractiveness of transport enterprises should be determined by calculating of the overall financial situation of enterprises, which will allow potential investors to evaluate profitability and cost efficiency of its activity. An analysis of the strengths and weaknesses of the enterprise engaged in transportation can be accomplished by the evaluation of its innovative capacity. The identification of factors and reserves of the increasing of enterprise innovative development will allow distinguishing of the basic directions for the improvement of organizational and economic mechanism of its activity. With the aim of building the strategy for the strengthening of market position it is also considered important for the potential investor to obtain the information about enterprise place on the national and international markets. Political and legal environment, characterized by political stability of society and the regulatory framework of entrepreneurial and investment activity serve as a certain guarantee of the investment reliability.
\end{abstract}

Keywords: innovative activity, investments and transportations. 


\section{Introduction}

Against the background of recent events in Ukraine, the recession of production, reduction of business activity of most entities significantly growing need for more active investment in all managerial levels. Because the investment processes are one of the levers of economic, political and social life. Ukraine's accession to the EU allowed the Ukrainian manufacturers to access on new markets and to be able to attract new foreign investors, this also applies to the transport industry. That is why it is especially important to pay attention to the questions of investment, the manner and the method of its activation, the study of conditions of creation of a favourable investment climate, attracting investments and their effective use.

Investment attractiveness of any enterprise is the so-called indicator, which allows the potential investor to analyze the feasibility of the finance investment in this object. The attractiveness of investing in infrastructure, most visible in the sphere of international transport transportations, is quite natural in connection with the interest of international corporations in the transit of goods through the territory of Ukraine. This interest is also due to the possibility of export from Ukraine of cheap raw materials and semi-finished products.

Ukraine has a developed transport network, which includes 22.3 thousand km of railways, 169,5 thousand. km of roads, nearly 3.0 thousand $\mathrm{km}$ of inland waterways, 19 sea ports and 10 river ports, 36 airports. Ukraine has registered 1059 transport enterprises.

All modes of transport transported annually 1.5 billion tons of cargo and 8.0 billion passengers. After prolonged and significant reductions of transportation work in the 90 -ies, since 2000 , transport has been a positive trend of growth in traffic. Transport of Ukraine is attractive for investment: fifth of the total investment in fixed assets accounted for the share of transport. With $80 \%$ of investments in transport-road complex is carried out at the expense of own funds of enterprises in the industry.

As a result of market transformations that are actively occurring in the transport sector, the share of the volume of cargo transportation to private entities is $50.0 \%$, including road transport - $72.0 \%$; according carriage of passengers $-42.0 \%$, automobile transport $-90.0 \%$. According to the Transport Strategy which was approved by the Cabinet of Ministers of Ukraine is expected that that by 2020 the volume of freight will amount to 2535 billion. tons, the volume of passenger transportation will amount to 10867,3 billion of passengers (Kontseptsia formuvanya..., 2000). Under such circumstances it is important is the development of Ukrainian enterprises engaged in transport transportations by attracting investment to their development, which requires an increase in their investment attractiveness.

The most important task of the methodology of investment attractiveness of enterprises is the search of objects that have the best prospects for the development and can provide the highest investment efficiency.

Full and correct methodology for determining the investment attractiveness of enterprises that are engaged in transport transportations would allow him regularly evaluate and identify problem areas for their elimination. In many enterprises innovative attractiveness is influenced by factors of internal and external environment. The internal environment is characterized by a set of interrelated and interdependent factors that determine the potential of the enterprise. The external environment is divided into direct and indirect environment impact.

The attractiveness of investment in infrastructure is most noticeable in the sphere of international transport transportations and is entirely legitimate, because of the interest of international corporations in the transit of goods through Ukraine. This interest is also due to the possibility of export from Ukraine of cheap raw materials and semi-finished products (Chernikova, 2009). Nevertheless, it is important to increase the investment attractiveness of transport industry.

\section{Literature review}

In modern economic literature there is no single definition of investment attractiveness of enterprise. There are a wide variety of scientist's opinions and practitioners for this reason. It is worth noting that most of them are not contradictory.

Numerous definitions of investment attractiveness of enterprises encountered in the economic literature, contain common features. Investment attractiveness is considered as an integral parameter (Yinkovyi, 2013):

- Relevance of investing;

- Level of the satisfaction of requirements or interests of the investor;

- Financial and property status and prospects of its development;

- Combination of objective and subjective (internal and external) conditions.

In Ukraine method of determining investment attractiveness based on the Regulation "On the implementation of the analysis of the financial condition of enterprises, which can be privatising", approved by the Ministry of Finance of Ukraine and the State Property Fund of Ukraine from January 26, 2001 №49/121 and registered in the Ministry of Justice of Ukraine in February 8, 2001 №121/5312. The main purpose of such methods served to ensure the organizational work that allows you to attract domestic and foreign investors for improvement enterprises and organizations, accelerate the implementation of investment projects. The 
calculation of the index of integral assessment of investment attractiveness is carried out by forming certain groups of indicators and the assignment of all groups of indicators of evaluation of investment attractiveness of enterprise. Indicators, which are included in the above groups of values, are assigned depending on their weight. The weight indicator is derived from the time, economic, political, social situation and other factors (Chernikova , 2009).

Usage of this technique for enterprises engaged in transportations has several advantages and disadvantages (Dextiar et al, 2007). Among the advantages: factors;

a) one indicator combined different name and units of measurement, weight and other performance

b) the indexes allow to analyze almost all areas of economic activity;

Scientists call disadvantages:

c) received a large amounts of the indicators does not actually permit a rapid evaluation of investment attractiveness;

d) in methodology there is not given scale of integrated indicators by which we can determine the financial condition of the enterprises, hence the inability to make a final conclusion about the quality of investment attractiveness;

e) sufficient complexity of payments through the large number of factors in groups.

Among the shortcomings and highlight the neglect of the study of innovative component, because the degree of wear of rolling stock on some business reaches critical indicators.

The financial aspect in assessing the investment attractiveness of transport enterprises using mathematical modelling, namely the formation of integrated assessment - analyzing by S.V. Yuhymchuk and S.D. Suprun (Suprun \& Uxymchuk, 2003). Scientists suggest to use matrix model based on generalized index that takes into account qualitative and quantitative criteria of enterprises condition. We believe that this technique is not in all cases meet the needs of investors in an objective, impartial, appropriate and sufficient for decisionmaking information.

\section{Research methods}

Methodological and informative fundamentals of work are scientific labours, materials of periodicals, Internet resources. During research conducting were conducted methods of structural and logical analysis, systems analysis and generalization.

Methodical researches of investment attractiveness must be based on logic of investment decisions, which foresees the investment of money wherein more favorable terms of investing. As ideal terms are not in the real practice, such decisions are accepted, usually by selecting a set of acceptable variants among possible. With this in mind, was developed logical scheme of search procedure, selection and investment decisions on the basis of comparison, which are kind of algorithm choices. Firstly, the investor chooses country of investing based on interstate evaluation of investment attractiveness, then a branch - based on intersectoral evaluation, then - the region - and thus to the level of a single project (Transportna stratehia...,2013). Such model of finding solutions for investors with uncertain goals in advance can be considered in our view as the most appropriate for businesses that are engaged in transportations. Because it allows investors with diverse interests and capabilities to assess the investment attractiveness of each level: country, sector, region, company, project and so on.

Evaluation of the investment attractiveness of enterprises, that is the link between the analysis stage and the stage of making decisions about investment, is an integral characteristic of individual enterprises as objects for long-term investment from the standpoint of sustainability, efficient use of assets, their liquidity, and a number of other indicators.

A full assessment of the investment attractiveness of enterprises involved in transportations should include all the components of this concept, namely, absolute and comparative methods for determining attractiveness of the enterprises as an investment object. The last place should occupy innovation component.

Representing the interests of capital, the investor should assess the degree of profitability of investments and the potential risks of investment. And therefore we consider it appropriate to increase the investment attractiveness of enterprises that are engaged in transportations, to carry out the assessment of the subject of investments not only for financial position, but also by using marketing analysis to allow you to evaluate not only the financial condition of the enterprise, and the environment in which it operates and prospects for further development (Dextiar et al, 2007).

To evaluate the investment attractiveness of the enterprise, which in our opinion best suited for the transport industry, using two groups of methods:

- analysis of business entity based on evaluation of its financial condition;

- comprehensive analysis of business entities. 
Methods included in the first group it impossible to make strategic investment decisions in the long run against the companies engaged in transportations and can be used in the process of resolving questions about on the feasibility of investing only in short-term perspective. Also, in the first case the attractiveness of the enterprise based on published information and enterprise reputation. In the second - the investor can evaluate the investment attractiveness of the enterprise, calculated on the basis of ranking highly professional con sulting companies with the help of the method, which is called in Western terminology "due diligence".

Due diligence - a comprehensive study of the activities, its financial situation and market position. Most often this term is used in finance and law. Used a short abbreviation - DueD, DDG or due diligence. Method includes collection and analysis of information, making a decisions and forms of its submission on whether the entry into certain relationships with contractors. With DueD are evaluated the possible risks (e.g. financial, legal etc.). While information collection - taken into account any data, regardless of source of its origin. There are some operations in the implementation of which is carried Due diligence: securities offering; mergers and acquisitions; large portfolio investments; execution of transactions of intellectual property and other (Gunko, 2013).

Unfortunately, at the present time the procedure of "due diligence" is used in Ukraine is quite rare because it is expensive and slow, it is recommended to use for large transport industry. But the technique itself involves a complex check of the enterprise by an external team of experts that according to many scientists, will allow attracting foreign investors, because for them the procedure DueD is considered to be normal commercial practice.

\section{Discussion of the results}

In our opinion the technique of investment attractiveness determination must contain minimum number of tables and indexes that contain data in which potential investor is interested. In addition, there are many indicators that duplicate information.

Not the last in the rating of investment attractiveness, especially with regard to enterprises engaged in transportations is its innovative component. The method of calculation of investment attractiveness provides the definition of innovative potential in the assessment of the indicator that allows performing the financial and economic state of the enterprise.

Most rating agencies consider Ukraine to be insufficiently attractive country for attracting investment. It is established that the main factors that negatively affecting on the investment climate and investment attractiveness of Ukraine are the following: macroeconomic instability, which is associated with multiple risks of investing of money in the country; low level of protection of foreign investors, which negatively affects the image of Ukraine; imperfect legislative regulation that adversely affects on the profitability of investments; corruption that blocks the flow of foreign investment, etc. (Kolesnyk \& Skorobogatova, 2015; Preiher et al, 2003).

Under such conditions, it is difficult to implement economic and innovative tasks aimed at increasing the attractiveness for the potential investors.

In our opinion, the methodology of evaluation of enterprise investment attractiveness of the transport industry should allow a potential investor to analyze enterprise in the following areas:

1. Determination of the financial position of the enterprise in which the property is assessed potential, liquidity, solvency, financial stability, cash flow, profitability, profitability, business activity and the probability of bankruptcy by calculating the metrics for determining the degree of investment risk.

2. Analysis of innovative potential of the enterprise. The main objective of this analysis is to assess internal and external opportunities that would ensure the competitiveness of the business entity and the realization of its goals in the competitive struggle in the future.

3. Industry analysis and definition of the niche of the enterprise (determination of the possibility and prospects of further development).

Objectively and comprehensively assessed properly will determine the expediency of investment, because it affects the end result that will get investors.

To increase the investment attractiveness of Ukraine transportation industry also consider it necessary to take action and in law: improving the legislative and executive framework; maintaining effective public policies at all levels; entry into the integration process; improve financial, tax, insurance and credit systems; expand cooperation with leading international organizations and rating agencies; strengthening the financial market; development of effective anti-corruption legislation; improving the business environment; improve the investment image of Ukraine; enhance the competitiveness of the economy, and so on.

Objectively and comprehensively has been made evaluation that will correctly determine the expediency of investment, because it affects the end result that will get investors.

With the aim of increasing the investment attractiveness of transport industry of Ukraine, also consider it necessary to take measures at the legislative level: improvement of the legislative-executive bases; maintaining an effective state policy at all levels of government; entry into the integration process; improvement of the 
financial, tax, insurance and credit systems; to expand cooperation with leading international organizations and rating agencies; strengthening the financial market; development of effective anti-corruption legislation; improvement of the business environment; improvement the investment image of Ukraine; to enhance the competitiveness of the economy, and so on.

\section{Conclusions}

In the current economic conditions there is an exacerbation of the problem of increasing the investment attractiveness of the enterprises that are engaged in transport transportations. Only the study and analysis of all interacting factors and indicators that affect the operation of the enterprise will allow making a conclusion about its status, and thereby ensuring transparency for potential investors and as consequence maximize socioeconomic impact of functioning of the transport industry and economy of Ukraine as a whole.

Among the key components of investment attractiveness of the transport enterprises we allocate its financial condition at the present stage of development of economic relations, which demonstrates to potential investors the reliability, stability and business activity. Competitiveness will determine the market niche occupied by the enterprise, and not the last indicator for its relevance allocated to the innovation component, given that the basis for the activities of the transport industry is the performance of rolling stock.

\section{Appendix A. Supplementary material}

Supplementary data associated with this article can be found, in the online version, at http://jsdtl.sciview.net

\section{Funding}

The authors received no direct funding for this research.

\section{Citation information}

Myshkovych, O. (2016). Conceptual and methodological approaches to evaluation of investment attractiveness of enterprises engaged in transportations. Journal of Sustainable Development of Transport and Logistics, 1(1), 34-39. doi: 10.14254/jsdtl.2016.1-1.6.

\section{References}

Chernikova, O. V. (2009). Zaluchennia investytsii u transportnu haluz Ukrainy [Attracting of investments in the transport sector of Ukraine]. Investytsii: praktyka ta dosvid = Investment: practice and experience, 12, 1617. (in Ukrainian).

Dextiar, N.A., Melnyk, I. O., \& Shkolnyk, I. O. (2007). Otsinka konkurentospromozhnosti ta investutsiinoui pruvablyvosti subiekyiv gospodariuvania [Assessment of competitiveness and investment attractiveness of economic entities]. Sumy, Ukraine: UABS NVU Publ. (in Ukrainian).

Hunko, V. I. (2013). Faktory ta pokaznyky formuvannia investytsiinoi pryvablyvosti pidpryiemstv [Factors and indicators of the formation of the enterprises investment attractiveness]. Finansovyi prostir = Financial space, 1(9), 58-88. (in Ukrainian).

Kolesnyk, Ya. O., \& Skorobogatova, N. Ye. (2012). Problemy vyznachennia investytsiinoi pryvablyvosti ta investytsiinoho klimatu $\mathrm{v}$ Ukraini [The problem of determining the investment attractiveness and investment climate in Ukraine]. Economic Journal. Retrieved from: http://economy.kpi.ua/ru/node/347. (in Ukrainian).

Kontseptsia formuvanya staloi natsionalnoi transportnoi polityky rozvytku vsikx vydiv transportu ta zasad (strategi) transportnoi polityky [The concept of the formation of a sustainable national transport policy of the development of all types of transport and principles (strategy) of transport policy]. Retrieved from http://www.insat.org.ua/files/other/news/020806/concept.doc. (in Ukrainian).

Preiher, D. K., Novikova, A. M., Maliarchuk, I. A., \& Hrynkevych, T.I. (2003). Tranzytnyi potentsial Ukrainy: realizatsiia ta rozvytok u konteksti rozshyrennia YeS [Transit potential of Ukraine: implementation and development in the context of EU enlargement]. Stratehichna panorama = Strategic view, 2. (in Ukrainian).

Suprun, S. D., Uxymchuk, C. V. (2003). [Matrix model of assessment of investment attractiveness of industrial enterprises] Finansy Ukrainy = Finance of Ukraine, 2(1), 3-12. (in Ukrainian). 
Transportna stratehia Ukrainu na period do 2020 skxvalena Rozporyadzheniam Kabinetu Ministriv Ukraini [Transport strategy of Ukraine for the period until 2020 approved by the Decree of the Cabinet of Ministers of Ukraine]. (2013). Uryadovuy kuryer, 240. (in Ukrainian).

Yinkovyi, O.G. (2013). Konkurentospromozhnist pidpryiemstva: otsinka rivnia ta napriamy pidvyshchenia [Competitiveness of the enterprises: assessment of the level and areas of improvement]. Odesa, Ukraine: Atlant Publ. (in Ukrainian).

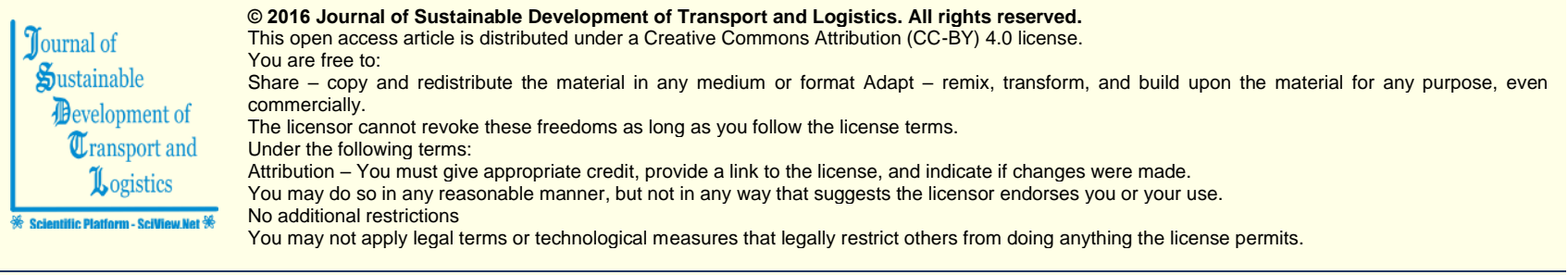

Journal of Sustainable Development of Transport and Logistics (ISSN: 2520-2979) is published by Scientific Publishing House "CSR", Poland, EU and Scientific Publishing House "SciView", Ukraine

Publishing with JSDTL ensures:

- Immediate, universal access to your article on publication

- High visibility and discoverability via the JSDTL website

- Rapid publication

- Guaranteed legacy preservation of your article

- Discounts and waivers for authors in developing regions

Submit your manuscript to a JSDTL at http://jsdtl.sciview.net/ or submit.jsdt|@sciview.net 